\title{
A Post-graduate View of Undergraduate PROGRAMS IN OCEANOGRAPHY
}

\author{
The popular misconception that all oceanographers \\ look for whales or the Titanic needs to be dispelled.
}

\author{
By Leslie K. Rosenfeld \\ The Cooperative Institute for Marine and Atmospheric Studies. \\ Rosenstiel School of Marine and Atmospheric Science. University of Miami, Florida.
}

\begin{abstract}
A pproximately 20 to 25 colleges and universities in this country offer undergraduate degrees in marine science or oceanography, with options in the sub-disciplines of biological, chemical, geological and physical oceanography (Maynard, 1986). In addition to these, there are a number of schools offering a degree in just one of the sub-disciplines (biology) or in related disciplines (fisheries, marine affairs, ocean engineering), and others allowing a student to concentrate in the marine sciences, while not actually offering a degree program as such. While in the past, there were a few institutions offering two-year technical Associate of Science (A.S.) degrees in the marine sciences, these programs appear to be on the decline. Now most undergraduate programs in the field offer the Bachelor of Science (B.S.) degree, with some of the less rigorous ones offering the Bachelor of Arts (B.A.) degree. How successful are these programs? Is there a real need for them?

What should be the role, if any, of undergraduate education in preparing tomorrow's oceanographers? This article will try to address these issues by considering what has become of the some of the people who have completed a fouryear undergraduate degree program in

oceanography. Did they pursue careers in the field, either with or without graduate education? Were they satisfied with the education they got? Do they wish they had chosen a different major? What contributions have they made to the oceanographic community as a whole? The answers to these questions will be based primarily on my personal experience and that of my friends and acquaintances. and some brief discussions with representatives of several academic departments offering undergraduate degrees in oceanography, and are not the result of extensive research into the subject. The focus here will be on physical oceanography because that is my area of expertise. It is also the area with the greatest employment opportunities at the moment, according to the University of Washington's current guide to undergraduate programs in oceanography. It is
\end{abstract}

certainly not, however, the area with the highest undergraduate enrollment. The vast majority of students receiving baccalaureate degrees in oceanography are concentrated in biology, followed by geology, chemistry and physics. I suspect that many of the opinions and conclusions offered here in regard to the value of an undergraduate education in physical oceanography may also apply to the other areas of oceanography.

Having said that this article primarily reflects my personal biases, let me give a quick overview of my background in oceanography. After briefly attending Tufts University (Medford, MA) and then sailing aboard the Sailing Education Association's (Woods Hole. MA) training research schooner Westward, I attended the Florida Institute of Technology, Jensen Beach Campus (recently defunct) from which I received an A.S. in Oceanographic Technology in 1976. I then transferred to the University of Washington from which I received a B.S. with a major in physical oceanography in 1978. During my undergraduate years I got some research experience by spending summers at the Harbor Branch Foundation in Ft. Pierce, FL and Columbia University's LamontDoherty Geological Observatory in Palisades. NY. Then after working for two years at the Naval Oceanographic Office (Bay St. Louis, MS) and The Johns Hopkins University`s Chesapeake Bay Institute (Baltimore and Shady Side, MD), plus a brief stint at Martin Marietta Environmental Center (Baltimore, MD), I entered the Woods Hole Oceanographic Institution / Massachusetts Institute of Technology Joint Program in Oceanography and Oceanographic Engineering, from which I received a $\mathrm{Ph} . \mathrm{D}$. in physical oceanography in 1987. I am now a postdoctoral associate at the Cooperative Institute for Marine and Atmospheric Studies at the University of Miami.

\section{Data}

I assume that I was asked to write this article because I was the only person the editor could think of who had both doctoral and bachelor's degrees in physical oceanography. While there may be one or two others of whom he and I are not
$W_{\text {hat }}$

should be

the role, if any,

of undergraduate

education in

preparing

tomorrow's

oceanographers? 
aware, I am sure the numbers are quite small. So what has happened to the other people who have completed undergraduate programs in physical oceanography? These sorts of statistics are hard to come by because most undergraduate academic departments do not track the careers of their graduates, although yearly enrollment figures in any given major are probably available.

My own inquiries show that while I may be one of the first physical oceanographers with both a Ph.D. and a B.S. in the field, I am certainly not going to be the last. I know of several Ph.D. candidates who majored in physical oceanography as undergraduates. Others are working on or have completed masters degrees. These individuals fill a wide variety of technical, management and research positions in academic, government, and industry settings. The opportunities for those who stop at the bachelor's level (or at least do not go on to graduate school immediately) are more limited in scope and possibly also in number, but it seems that most who want to pursue careers in oceanography are able to find jobs. (This may not apply to those in biological oceanography.)

According to the deans' offices at University of Washington (UW), Florida Institute of Technology (FIT), and University of Miami (UM), a majority of their marine science undergraduates go on to graduate school or are employed in an oceanographic capacity. Many are research assistants in academic and research institutions or government laboratories, getting involved in field work and data-processing. Some are shipboard technicians, while others go into computer programming slots. Some no doubt also find their way into private industry. While the duties of an employee at this level may be somewhat tedious and the chances for advancement limited, I imagine that the situation is no different in the rest of the sciences.

One potential indicator of the success of these programs, the trend in the number of enrollees, yields inconclusive results. FIT says that their total number of undergraduates in oceanography and ocean engineering is declining, while UM's enrollment is holding steady, and UW's is increasing. Are students from all of the four-year undergraduate programs equally likely to pursue careers in oceanography? If the people I have met during the course of my 14 years in oceanography are typical, then the answer is no. Only eleven institutions (Table 1) are represented by this group. At least some graduates from a substantial subset of these same institutions have been accepted into the top graduate schools in oceanography.

There is no apparent dichotomy between the programs that are most successful in placing students in the job market and those that are best at preparing them for graduate school. Only a very small percentage of the students admitted into graduate schools in oceanography have undergraduate degrees in the marine sciences, leading at least to the perception, if not the fact, that students with this major are not competitive, in this regard, with students who major in the basic sciences. I suspect that undergraduate oceanography majors are actually underrepresented in graduate oceanography programs, even taking into account the small proportion of undergraduates who major in oceanography versus other subjects. This may be due in part to the fact that these students are not applying in great numbers, the ones planning on graduate school having been earlier advised to major in one of the basic sciences. Of those who do apply, their lack of competitiveness may be attributed to some combination of deficits in the candidate (probably fostered by the low degree of selectiveness in admissions to undergraduate programs) and in the candidate's undergraduate curriculum. Both the distribution of courses by subject and the degree of difficulty of the courses affect the quality of the curriculum. Maynard's 1986 survey of 27 marine science baccalaureate curricula from ten institutions (partially overlapping with those listed in Table 1) and 28 curricula recommended by ten graduate institutions found strong similarities between the courses undergraduate programs offered and the ones graduate schools said they wanted their incoming students to have taken. This suggests that course requirements should not be a major factor in preventing undergraduate oceanography majors from continuing on to graduate school.

\section{Ingredients For A Successful Program}

What are the essential components of a successful undergraduate program in oceanography? A series of informal interviews with oceanographers who majored in the field as undergraduates quickly revealed that the most important element of their undergraduate years, the thing that was most responsible for them pursuing careers in oceanography, was research experience. In some cases, this experience came in the form of a work co-op program or intensive summer field course. In other cases, students had the opportunity to work on projects with members of the regular teaching staff, or with adjunct faculty or research staff. For my own part, the summer internships I served at research institutions gave me an inside look at some practicing oceanographers, and helped me to focus my own interests.

A second key element was the strong emphasis on one of the basic sciences. Some programs even recommend or require a double major. Programs offering a more general oceanography degree, without specialization in one of the sub-disciplines, were felt to be much less worthwhile. Good advising with respect to course selection and job opportunities are also important parts of a successful program.

\section{Pros And Cons}

Even considering just the best undergraduate oceanography degree programs, can we establish a need for this type of education? Rather than attempt to analyze the sketchy data available, I will attempt to present in a more general way some of the advantages and disadvantages to the individual and the community of these programs based on my own experiences and the opinions culled from discussions with others in the field. 
To the college-bound high school senior who is interested in the marine sciences, the primary advantage of a school offering an undergraduate program in oceanography, is the fact that you do not have to wait for four years to satisfy your desire to immerse yourself in the subject. This was the major drawing card for me. If I had not had the option of majoring in oceanography, I might not have continued in college at that time. I had already dropped out of one university, where it seemed to me that all the science classes were geared to pre-med majors.

A second advantage, one with more long-lasting benefits, is the exposure to all aspects of oceanography. Introductory courses taken in the first two years (or in my case in a two-year degree program before transferring to a four-year program) help you to decide what sub-discipline of oceanography to concentrate in, and background in the others is helpful whichever you choose, particularly in view of the growing emphasis on interdisciplinary studies. As the body of knowledge in oceanography grows, graduate students are forced to narrow their area of expertise, due to the pressure to finish in a reasonable period of time. The opportunity to take courses outside your area of specialization is fading. It is quite possible for an undergraduate math or physics major to complete a doctoral program in physical oceanography without ever having to take courses in biological, chemical or geological oceanography. The broad view of oceanography one gets in an undergraduate program is a strong point in their favor.

A third advantage is that students who major in oceanography as undergraduates can make a more informed decision about whether they want to go on to graduate school. Many people entering graduate school in oceanography from other backgrounds do not have a good feel for what they are getting into.

For those who suspect they want to go on to graduate school in oceanography, there are some disadvantages to majoring in oceanography as opposed to the more traditional approach of majoring in one of the basic sciences, of which they should be aware. This choice may affect not only their chances of getting into graduate school and their subsequent performance there, but also may have consequences throughout their entire careers. Oceanography majors generally take fewer courses in the "pure" science (physics in my case) and fewer math courses. In some programs there is also a question as to the caliber of the courses. Students applying to schools requiring advanced GREs in a special subject may find this a particular difficulty.

Then, even if a student has completed a tough program with good grades and GRE scores, he or she may still face some discrimination at graduate school admission time.

Those passing the hurdle of admission may experience some difficulties during the first year in graduate school, as they find that they are ahead of their classmates in some subjects and behind in others. A more enduring problem which can result from a weaker foundation in the basic science underlying your chosen sub-discipline of oceanography is a lesser degree of familiarity with how certain problems have been solved in closely-related subjects. For instance. I may not pick up on an analogy between a problem in geophysical fluid dynamics and one in. say, electromagnetism or thermodynamics. as easily as someone who became more familiar with those subjects during their undergraduate studies.

Students who are fairly certain they want to go on for an advanced degree, but are unsure in what field, are almost definitely better off majoring in one of the basic sciences because it leaves them more flexibility, although I do know oceanography majors who have gone on to medical school, for example. I would make the same recommendation to students who do not think they want to go on to graduate school, and are not committed to working in oceanography after finishing undergraduate school. Computer science, engineering, or statistics majors, as examples, will have a wide range of opportunities for employment, including jobs in oceanography.

The oceanographic community as a whole benefits from undergraduate oceanography programs in that they can act as a recruitment mechanism for graduate schools, and they are a source of qualified motivated people to fill research assistant and other positions. Possible disadvantages are that they can dilute the resources of an institution and. at places with both undergraduate and graduate programs, faculty must take time to teach undergraduate courses. which might otherwise be spent on graduate courses or research.

\section{Conclusions And Recommendations}

On balance, I think that for a certain group of students, those who know early on that they want a career in oceanography, the advantages offered by a good undergraduate marine science program outweigh the disadvantages, and this educational route can be a rewarding alternative to the more traditional approach. It is also my feeling that there is a legitimate place in oceanography for people with this background and they need not suffer for career opportunities. If we accept this premise, then it is useful to consider what can be done to improve undergraduate programs in oceanography and the way they fit into the rest of the educational system.

First of all, high school seniors and college freshmen and sophomores need better information about what oceanography is and what is available in the way of educational and employment opportunities. The popular misconception that all oceanographers look for whales or the Titanic needs to be dispelled.

Secondly, if possible. undergraduate oceanography programs should be more selective in their admissions. Increasing the difficulty of the undergraduate curriculum will also help to improve the quality of the students who complete it, thus helping them to be more competitive when applying for spots in graduate schools, and enhancing the reputation of the undergraduate program. [ PLEASE TURN TO PAGE 35 ]

\section{The primary}

advantage of $a$

school offering

undergraduate

programs in

oceanography is

the fact that you

do not have to

wait for four

years to satisfy

your desire to

immerse yourself

in the subject. 


\section{A Post-Graduate VieW [ CONTINUEd From Page 13 ]}

Thirdly, graduate schools need to recognize that entering students come from a variety of backgrounds, each with its own inherent strengths and weaknesses. Some allowance must be made for this in the graduate curricula.

One step that has been taken in this direction by the Joint Program is the introduction of a math course in the first summer. designed to help ensure that students do not start their first semester with a disadvantage in this area. Finally, departments offering bachelor's degrees in oceanography should track their graduates and see how they have fared in their further education and careers. This information, along with statistics from graduate departments of oceanography on the rate of acceptance of applicants and the fate of the admittees, classified by undergraduate major, should be useful in future evaluation of under- graduate programs.

\section{REFERENCES}

Maynard, S.D. 1986. Undergraduate marine science degrees: pros and cons Proceedings of the Pacific Congress on Marine Technology, PACON 86. Honolulu, MRM7: 38-46.

TABLE 1. A PARTIAL LIST OF INSTITUTIONS OFFERING BACHELOR'S DEGREES IN OCEANOGRAPHY OR MARINE SCIENCE. Florida Institute of Technology, FL

Humboldt State College. CA

Millersville State College, PA

Southampton College, NY

Stockton State College, NJ

Texas A\&M University at Galveston, TX

U.S. Naval Academy, MD

University of Miami, FL

University of Michigan, MI

University of South Carolina, SC

University of Washington, WA

\section{Satellite OCEan Color [ Continued From Page 20 ]}

Gordon, H.R., J.W. Brown and R.H. Evans. 1988. Exact Rayleigh scattering calculations for use with the Nimbus-7 Coastal Zone Color Scanner. Applied Optics 27:862-871.

Holligan, P.M. V. Viollier, D.S. Harbour, P. Camus, and M.ChampagnePhillippe. 1983. Satellite and ship studies of coccolithophore production along a continental shelf edge. Nature 304:339-342.

Joint EOSAT/NASA SeaWiFS Working Group. 1987. System concept for wide-field-of-view observations of ocean phenomena from space. EOSAT. 4300 Forbes Blvd. Lanham. MD 20706.

McClain. C.R. L.J. Pietrafesa and J.A. Yoder. 1984. Observations of Gulf Stream-induced and wind-driven upwelling in the Georgia Bight using ocean color and infrared imagery. J. Geophys. Res. 89:3705-3723.

Perry, M.J. 1986. Assessing marine primary production from space. Biosci.
36:461-467

Rampino, M.R. and T. Volk. 1988. Mass extinctions, atmospheric sulphur and climatic warming at the K/T boundary. Nature 33i:63-65.

Smith. R.C.. O.B. Brown, F.E. Hoge, K.S. Baker. R.H. Evans, R.N. Smith and W.E. Esaias, 1987. Multiplatform sampling (ship, aircraft, and satellite) of a Gulf Stream warm core ring. Applied Optic's 26:2068-2081.

U.S. Global Ocean Science Program Working Group. 1987. The U.S. Global Ocean Science Program, A strategy for understanding the role of the ocean in global change.

Yoder, J.A.. C.R. McClain, J.O. Blanton and L.-Y. Oey. 1987. Spatial scales in CZCS-chlorophyll imagery of the Southeastern U.S. continental shelf. Limn. Oceanogr.32:929-941.

\section{OPTICAL OCEANOGRAPHY [ CONTINUED FROM PAGE 23 ]}

\section{ACKNOWLEDGMENTS}

There are some $80-100$ researchers active in ocean optics in the Western world. Regrettably, space did not allow fair representation of all their efforts, past and present. The author is indebted to the community as a whole. Several individuals are owed special thanks for their comments and advice: Ros Austin. Ken Carder. Howard Gordon, Frank Hoge, Curt Mobley, Hasong Pak, Ray Smith, Charlie Yentsch and Ron Zaneveld.

\section{REFERENCES}

Baker, E.T., J.W. Lavelle, and G.J. Massoth. 1985: Hydrothermal particle plumes over the southern Juan de Fuca Ridge. Nature, 316:342-344.

Bauer, D. and A. Morel, 1967: Etude aux petits angles de l'indicatrice de diffusion de la lumiere par les eaux de mer. Ann. Geophys.. 23:109-123. Biscaye. P.E. and S.L. Eittreim, 1977: Suspended particulate loads and transports in the nepheloid layer of the abyssal Atlantic Ocean. Mar. Geol., $23: 155-172$

Secchi, A.. 1866: Relazione della esperienze fatta a bordo della Pontificia Pirocorvetta L'Imacolata Concezione per determinare la transparenza del mare /Reports on experiments made on board the Papal steam sloop L Imacolata Concezione to determine the transparency of the sea] in Sul moto ondoso del

mare e su correnti di erso specialmente su quelle littorali, by Comm. Dept. of the Navy Office of the Chief of Naval Operations. O.N.I. Trans. No. A-655. Op-923 M4B, 21 Dec., 1955.

Smith. R.C. and K.S. Baker. 1978: The bio-optical state of ocean waters and remote sensing. Limnol Oceanogr. 23:247-259.

Spinrad, R.W. and J.R.V. Zaneveld. 1982: An analysis of the optical features of the near-bottom and bottom nepheloid layers in the area of the Scotian Rise. J. Geophys. Res., 87:9553-9561.

Thorndike,E.M. and M. Ewing, 1967: Photographic nephelometers for the deep sea in Deep-Sea Photography, v. 3 Johns Hopkins University Press, pp. $113-116$.

Weatherly, G.L., E.A. Kelley, J.R.V. Zaneveld, H.Pak, M.J. Richardson. 1980: A deep narrow, thin filament of the western boundary undercurrent. EosTrans. AGU, $61: 1016$.
The

Yentch, C.S. and D.W. Menzel, 1963: Absorption curves of acetone extracts of deep water particulate matter. Deep-Sea Res.. 10:443-448.

Yentsch, C.S. and J.H. Ryther, 1959: A method for the determination of phytoplankton chlorophyll and phaeophytin by fluorescence. Deep-Sea Res. $6: 72-74$.

\section{OCEANOGRAPHY SOCIETY [ CONTINUED FROM PAGE 21]}

strength to a society in their own specialty. A new society would provide a mechanism for evaluating this strength, for focusing it , and maximizing its application. The changes which can be brought about in the world of social organizations by the activities of The Oceanography Society could well be comparable to the changes which were brought on-campus by the establishment of oceanography departments.

As in the universities, where all departments cooperating in the marine sciences saw those programs strengthened by the existence of an oceanography department in their midst, it is likely that the ocean-oriented programs of brother societies would be strengthened by their association with The Oceanography Society. A broader and deeper basis for support of all applications of ocean science, engineering, and technology could be tapped.
The potential of oceanography seems unlimited. The oceans constitute a major part of our planet. Understanding and fully utilizing the oceans will require all the knowledge of the basic sciences and all of the skills of engineering and technology. To obtain appropriate support and to seek this understanding effectively requires the coordination and focusing of the many different participating institutions and societies. A missing element has been a dedicated Oceanography Society.

\section{REFERENCES}

Knudsen, Vern O., Redfield, A. C.. Revelle. R., and Shrock. R. R., Education and Training for Oceanographers, Science, 111 (2895), p. 700-703. June 23. 1950.

Leipper. Dale F. The establishment of the Department of Oceanography in the Agricultural and Mechanical College of Texas [Now Texas A\&M University)] Trans. Am. Geophys. Un. 3I ( 5), October 1950.

Leipper, Dale F., Oceanography - A definition for Academic Use, Trans. Am. Geophys. Un. 42 (4), December 1961. 